\title{
Climate change adaptation strategies for smallholder farmers in the Brazilian Sertão
}

\author{
Jennifer Burney • Daniele Cesano • Jarrod Russell • \\ Emilio Lèvre La Rovere • Thais Corral • \\ Nereide Segala Coelho • Laise Santos
}

Received: 23 July 2013 / Accepted: 9 June 2014 /Published online: 22 July 2014

(C) The Author(s) 2014. This article is published with open access at Springerlink.com

\begin{abstract}
Climate models agree that semi-arid regions around the world are likely to experience increased rainfall variability and longer droughts in the coming decades. In regions dependent on agriculture, such changes threaten to aggravate existing food insecurity and economic underdevelopment, and to push migration to urban areas. In the Brazilian semi-arid region, the Sertão, farmers' vulnerability to climate — past, present, and future — stems from several factors, including low yielding production practices and reliance on scarce and seasonally variable water resources. Using interpolated local climate data, we show that, since 1962, in the Bacia do Jacuípe - one of the poorest regions in the Sertão of Bahía state - average temperatures have increased $\sim 2{ }^{\circ} \mathrm{C}$ and rainfall has decreased $\sim 350 \mathrm{~mm}$. Over the same time period, average milk productivity - the main rural economic activity in the county - has fallen while in Brazil and in Bahía as a whole milk productivity has increased dramatically. This paper teases apart the drivers of climate vulnerability of the Bacia do Jacuípe in relation to the rest of Bahía. We then present the results of a suite of pilot projects by Adapta Sertão, a coalition of organizations working to improve the adaptive capacity of farmers living in the semi-arid region. By testing a number of different technologies and arrangements at the farm level, Adapta Sertão has shown that interventions focused on balanced animal diets and efficient irrigation systems can help reduce (but not eliminate) the dependence of production systems
\end{abstract}

Electronic supplementary material The online version of this article (doi:10.1007/s10584-014-1186-0) contains supplementary material, which is available to authorized users.

\author{
J. Burney $(\bowtie) \cdot$ J. Russell \\ University of California San Diego (IRPS), San Diego, CA, USA \\ e-mail: jburney@ucsd.edu \\ D. Cesano $\cdot$ T. Corral \\ REDEH-Rede de Desenvolvimento Humano, Rio de Janeiro, Brazil
}

E. L. La Rovere

Cento Clima/UFRJ, Rio de Janeiro, Brazil

N. S. Coelho $\cdot$ L. Santos

Cooperativa Ser do Sertão, Pintadas, Bahia, Brazil 
from climate. They are thus viable adaptation strategies that should be tested at a larger scale, with implications for semi-arid regions worldwide.

\section{Importance of climate change for smallholder farmers}

Family farmers in Brazil are responsible for $\sim 70 \%$ of the food consumed by the Brazilian population (MDA 2012). At the same time, smallholder farmers ${ }^{1}$ living in semi-arid Brazil are also considered the most vulnerable sector of Brazilian society to climate change impacts (Simões et al. 2010). These anticipated impacts range from reduced productivity to outmigration of labor due to increased economic strain (Lobell et al. 2008; Lobell et al. 2011; Assad et al. 2013).

Why are smallholder farmers vulnerable to climate change? No accepted consensus at present exists on the precise definitions of climate vulnerability, resilience, or adaptive capacity. The original ecological conception of resilience (Holling 1973) nevertheless applies here: a climate-resilient smallholder farming ecosystem is one in which farmers thrive even as baseline agroecologic conditions change. Conversely, a vulnerable system is one in which state changes in climate variables threaten the viability of smallholder farms. While farmers may have some degree of coping capacity (for example, assets that may be depleted in a given year to overcome a climate shock), their adaptive capacity - their ability to adjust to and thrive in changing conditions - is what drives resilience in the longer run (e.g., Berman et al. 2012).

Existing literature characterizes the vulnerability of Brazil's smallholder farmers in the semi-arid northeast as a function of (a) the climate sensitivity of their production systems, (b) overall poverty levels (i.e., a lack of coping capacity), and (c) institutional weaknesses leading to a lack of overall adaptive capacity (e.g., Simões et al. 2010). On the physical side, climate models show enormous potential impact of future climate changes on the hydrology of the semi-arid region of Brazil, affecting river flow, water storage and irrigated production (Krol and Bronstert 2007; Silva et al. 2010). Models combined with hydrological observations from catchments in the area indicate the possibility of substantial reduction in surface water availability (Montenegro and Ragab 2012) and an ongoing process of environmental dryness (Rodrigues da Silva 2004). Indeed, integrated modeling studies show that water management is a key question for the development and sustainability of the semi-arid region of Brazil (e.g., Krol et al. 2006).

At the same time, farmers in the northeast region of Brazil are poor. This region received over $50 \%$ of the national anti-poverty cash transfer program, "Bolsa Familia", in 2011, despite representing only $25 \%$ of the population (D'Andrade 2012). Overall service provision in the northeast is also low (IGBE 2006). As such, farmers in the area lack coping capacity. Perhaps most perversely, adaptation to climate change (including resiliency for smallholder farmers) is still most frequently discussed as though it is a far-off future need. As such, little has been done to build the adaptive capacity of farmers in the semi-arid region though targeted research and development and longer-run policies, or to create an integrated development and adaptation strategy for impoverished smallholder farmers (Simões et al. 2010).

In this paper, we ask four questions: (1) How has climate change in recent decades impacted land use and agricultural production in the semi-arid northeast? (2) What do these land use and productivity changes tell us about the vulnerability of farmers to climate change?

\footnotetext{
${ }^{1}$ The federal definition "smallholder" is based on socioeconomic status and rural classification, and varies according to region. In this study area, smallholders are defined as owning less than 70 ha of land. All of the farmers fit this criteria, and live on their farms (they are small family operations). As such, we use the terms smallholder and family farmer interchangeably here.
} 
(3) Among the technologies and interventions currently promoted by the government (at various levels), how can we quantify which effectively build adaptive capacity among smallholders? (4) Finally, how might results from tests of these technologies inform a more forward-looking, integrated development and adaptation policy environment in the northeast and in Brazil as a whole?

To answer these questions, the paper proceeds as follows: Section 2 describes the study context and methodology; Section 3 presents results from interpolated climate data at the municipality level, and teases apart the dynamics of climate vulnerability in the study region. Section 4 examines the results of several pilot tests of technologies meant to enhance climate resilience of smallholders and evaluates them in the context of regional vulnerability. Section 5 discusses these results in the climate vulnerability framework, and Section 6 offers policy lessons and conclusions to be drawn from the study.

\section{Study design and methodology}

\subsection{Study region}

The Brazilian Sertão (Fig. 1) is the largest semi-arid area in Latin America, in both size and population, at $\sim 900,000 \mathrm{~km}^{2}$ and more than 20 million people. Public policy makers have long focused on the Sertão due to the poverty in the region. Regional economic and social indicators in the Brazilian semi-arid are well below the national average, with a yearly Gross Domestic Product (GDP) per capita of $\sim \mathrm{R} \$ 2,000$ to $\mathrm{R} \$ 3,000$ (\$1,000 to $\$ 1,500 \mathrm{USD}$ ), which is up to eight times lower than areas like the city of São Paulo, the industrial capital of Brazil (IBGE 2006). The Sertão is further characterized by a large imbalance in land ownership, and most of the impoverished are smallholder farmers. However, beyond structural economic disparities between small and large-scale farmers, the Sertão is subject to difficult environmental conditions. Average rainfall in the region is around $600 \mathrm{~mm}$ per year but varies tremendously over both time and space, with the variability making planning difficult for smallholders. The period from 2010 to 2013 featured the worst drought in 60 years, with devastating consequences on the local economy. Given that climate models agree on a number of likely future

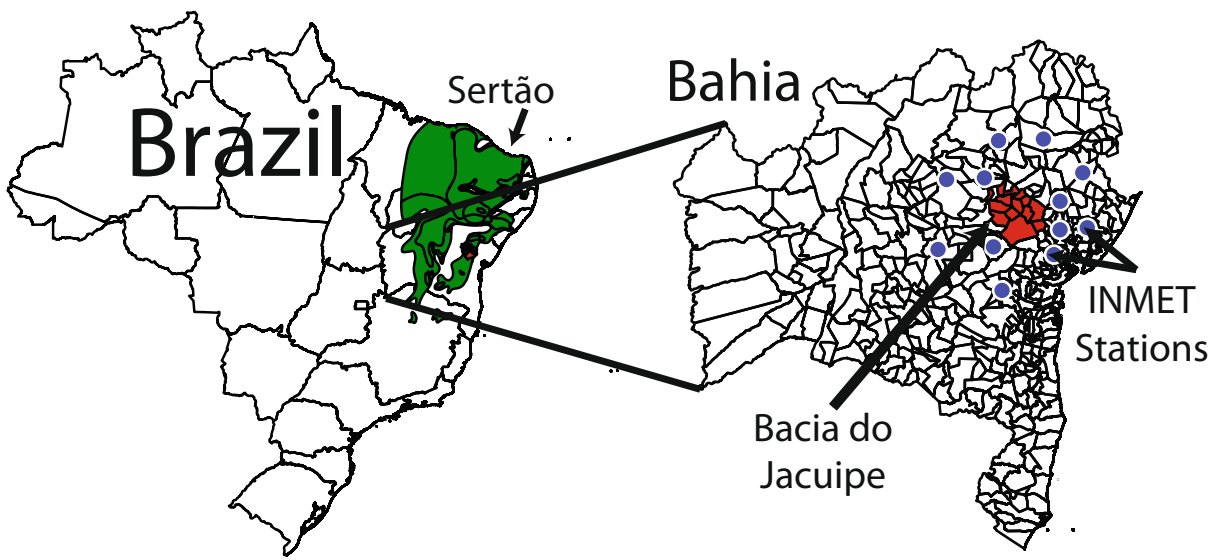

Fig. 1 Study Region. The Sertão ecoregion of Brazil, the state of Bahía, with the Bacia do Jacuípe (BDJ) in red. INMET weather stations closest to BDJ are indicated with blue dots. (See SI for a list of BDJ municipalities and INMET stations used in this analysis) 
changes in the region - increased rainfall variability and drought, intensification of the hydrological deficit - understanding and addressing the adaptation possibilities for the region's most vulnerable populations is critical.

Our study focuses on the Bacia do Jacuípe county (hereafter BDJ), a territory within the Sertão in Bahía State that encompasses 14 contiguous municipalities over 10,612 km² (Fig. 1). BDJ is a predominantly agricultural area; Bahía is also an important agricultural state. Over the past several decades, however, the agricultural patterns of BDJ have changed and it has not shared in Bahía's overall trend of increasing farm productivity. As such, it is an ideal location for understanding and characterizing smallholder climate vulnerability and for testing technologies and policies with potential to build resilience.

This work was conducted in conjunction with a local umbrella organization, Adapta Sertão. Adapta Sertão (www.adaptasertao.net) is a coalition of organizations created in 2006 to identify and test possible adaptation strategies for smallholder farmers, who otherwise lack funding and technical support, and to then implement and disseminate them across the region. The objective of Adapta Sertão is to create a community of NGOs, farmers' cooperatives, and research and public policy institutions that foster long-term resilience for smallholder farmers. (Early work by the coalition has been described in Obermaier et al. 2009 and Simões et al. 2010; the organization is described in further detail in the Supporting Information.)

\subsection{Methodology for climate trends detection}

As a first step to understanding regional climate vulnerability, we examined climate trends in BDJ over the past half-century. Climate data was sourced from weather stations owned and operated by Brazil's National Meteorological Institute (INMET). Due to the absence of weather stations within BDJ (see Fig. 1), daily insolation, precipitation, and temperature data were interpolated from the 12 nearest-neighboring stations. Data were interpolated for each day between January 1, 1962 and December 31, 2012 and then aggregated over time and space for municipality and county level seasonal and annual statistics. In addition to average temperature and insolation metrics, and total precipitation indicators, we also examined rainfall intensity, using common rainfall rate (RR) indices to divide BDJ's precipitation into five categories: dry days $(R R=0 \mathrm{~mm})$, damp days $(0<R R \leq 1 \mathrm{~mm})$, wet days $(R R>1 \mathrm{~mm})$, very wet days $(R R \geq 10 \mathrm{~mm})$, and extremely wet days ( $R R \geq 25 \mathrm{~mm})$. In addition, we also calculated the maximum number of consecutive dry days each year (a measure of seasonal drought). Finally, beyond annual trends, we also examined trends for three rainy seasons in BDJ (identified empirically and corroborated in focus group interviews).

For the analysis from 1962 and 2012, years missing more than $10 \%$ of daily data were intentionally excluded. Several of these years coincide with severe droughts during the first half of the 1980s and again in the early 1990s. The droughts reportedly caused INMET weather stations around BDJ to shut down, meaning this analysis omits some severe weather events due to insufficient data. However, a sensitivity analysis was performed to determine the effect of this data gap on the trends analysis; the missing years were shown to have an insignificant impact on the overall trends analysis of BDJ's climate.

\subsection{Methodology for adaptation technology testing}

Research in semi arid regions around the world has investigated several different technologies and strategies for coping with persistent droughts and hydrological stress. Water harvesting systems for supplemental irrigation, strategies to maximizing plant water availability and plant water uptake capacity, conservation tillage systems, storing excess crop harvests during good 
years, conservation agriculture, low-impact grazing strategies, use of drought resistant plants Leucaena leucocephala and Opuntia ficus-indica for fodder production and recession agriculture on the margins of reservoirs have all been shown to have at least some degree of success (Lima 1986; Rockström 2003; Archer 2004; Antonino et al. 2005; Dubeux et al. 2006; Jat et al. 2012; Mogotsi et al. 2013; Gutiérrez et al. 2014). The key challenge, however, remains in the identification of the most successful combination of possible strategies and technologies in a particular context and in its dissemination mechanism over a very large scale to reach the largest number of farmers. We conducted baseline surveys to identify candidate technologies to test.

In a survey of 350 smallholder farmers across BDJ, two clear patterns emerged that guided the choice of resiliency technologies. The first was underutilization of existing water resources. The survey revealed that local crop production in BDJ is almost entirely rain-fed (in the case of staples, mainly maize and cassava) or hand irrigated (vegetables): only 4 farmers out of the 350 surveyed were using irrigation equipment. Nevertheless, almost all farmers surveyed had access to at least one source of water, though these were most frequently ephemeral in nature (lasting up to 12 months maximum, but often dry for several months at a time). This underutilization of smallholder water management technologies persists in spite of the fact that, over the past half-century, the Brazilian government has constructed hundreds of small earth dams and wells to help with annual "smoothing" of seasonal water resources.

Second, the survey showed that average milk productivity in the region is $7 \mathrm{l} / \mathrm{cow} / \mathrm{day}$ during the lactation period of the animal. Potential milk productivity is much higher; and this "yield gap" appears at least in part to be due to mismanaged feeding. Farmers report buying protein-enriched feed, like cotton or soy meal, with the hope of increasing milk productivity but they provide the animals with miscalculated quantities, mostly due to lack of information / technical assistance. The result is that farmers can give up to $300 \%$ more protein than the animal needs, and often in an unbalanced way, which results in substantially lower milk productivity and reduced farm revenue. (A similar pattern was noted for meat production (goats), with farmers feeding animals a non-balanced diet and animals not growing as much as expected.)

Based on these patterns of farm activity throughout BDJ, Adapta Sertão conducted pilot tests of small-scale irrigation systems to improve food production, and of education on balanced animal feed practices to increase milk and meat productivity.

Irrigation Sixteen farmers using drip irrigation systems (out of 40 total) were selected and monitored regularly for a period of 2-5 years to understand the income, labor, and maintenance and operations costs - as well as the risks - associated with adoption of irrigation. Only eight of those farmers were able to use the system for more than 12 months continuously during that time due to water constraints (2010-2012 was a period of tremendous drought). Five of the farmers who stopped using an irrigation system during the pilot test did not have enough water to use it more than a few weeks per year; the remaining three farmers had access to water but decided it was not worthwhile to pursue irrigation on their own farms. Data from the continuous users, as well as preliminary diagnostics for predictors of successful use are presented in the results section below.

Milk production To conduct a pilot assessment of balanced animal feeding practices, Adapta Sertão performed a 2-month experiment with five different farmers. Three farmers separated some of their animals from their herd (6 cows the first farmer and one cow each for the second and third farmers) and fed them in confined settings (to monitor intake). In the first stage, farmers used their traditional feed for their animals. Technicians recorded milk production per 
animal, value of milk per liter, and cost of feed per kilogram over the course of 1 month. In the second stage, farmers fed them a diet optimized for voluminous roughage, energy, and protein for 1 month. Milk productivity on the new diet was compared to baseline.

Farmers in BDJ have two main breeds of dairy cattle - Sindi and Girolandia. Sindi are smaller animals, with peak production of $\sim 101$ per animal per day under optimized diet; Girolandia are larger and can peak over 201 per animal per day with optimized diets. Baseline milk production in extensive systems (100\% pasture, no protein/energy complements) is around 2-5 1 per cow per day. With some protein complements, the baseline rises to 5-7 1 per animal per day. A typical baseline in BDJ, therefore, is assumed to be around 71 per day; i.e., animals are being given some protein in addition to forage, but the ratio has not been optimized.

Meat production To test the impact of balanced feeding practices on meat production, a similar experiment was conducted with two farmers and 29 goats (10 and 19 goats from the two farms), comparing weight gain with a balanced diet to baseline feeding practices. Farmers fed the goats for 1 month as they had been before; in the second stage, each farmer was responsible for mixing the specified feed balance as dictated by the availability of the forage varieties grown on his or her property (e.g. prickly pear cactus, sorghum, etc.). The idea was to use all forage the farmer had available in his/her property and balance it with the right amount of protein and energy content. The use of protein- and energy-rich feeds purchased in local retailers (cotton and soy meal; corn) was necessary to balance the energy-protein-volume ratio. By using a comparison of before- and after-intervention data for each animal, potential benefits from the experiment were measured, including profitability and an understanding of carrying capacity of the farmers' roughage production.

\section{Historical climate changes and the dynamics of vulnerability in BDJ}

\subsection{Climate trends}

Analyses of 50 years of interpolated data for BDJ reveal statistically significant meteorological trends (Fig. 2). From 1962 to 2011, annual mean of daily minimum and maximum temperatures increased between 1.95 and $2.1{ }^{\circ} \mathrm{C}$, varying slightly by municipality. Average precipitation decreased between 300 and $450 \mathrm{~mm}$ over the region, which corresponds to a $30 \%$ decrease. All measurements for temperature and precipitation are statistically significant at $99 \%$. RR indices also show significant trends over the last half century. When comparing average annual precipitation distributions between the first 20 years (1962-1981) and last 20 years (19922011), the number of wet days decreased, while the number of damp days increased (Fig. 2b). In other words, the precipitation distributions have changed significantly, in addition to total precipitation: heavier nourishing rains have been replaced by lighter drizzle days.

Comparisons of relative changes in precipitation and temperature across BDJ demonstrate commonalities and divergences between its 14 municipalities. All BDJ municipalities are getting drier and warmer, with a range of -5 to $-10 \mathrm{~mm}$ in annual precipitation loss and 0.038 to $0.042{ }^{\circ} \mathrm{C}$ increase for average daily annual maximum temperature (Fig. $2 \mathrm{c}$ and d).

\subsection{Agricultural trends and dynamics of vulnerability}

Since the mid 1970s, data show that farmers in BDJ have increasingly turned to milk production for their livelihoods. Dairy farming represents a form of intensification: it typically 

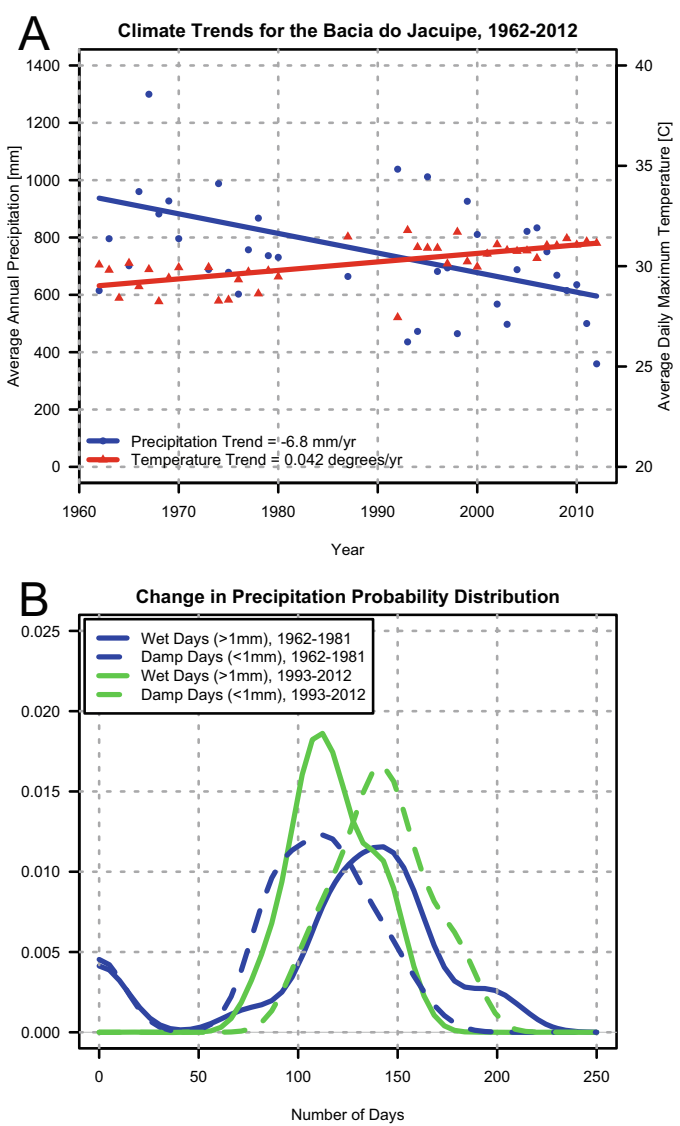

C Average Daily Maximum Temperature Trend Degrees [C] per year, 1962-2012

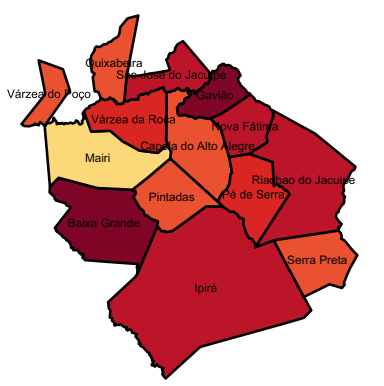

0.0380 .03850 .0390 .03950 .040 .04050 .0470

D

Average Total Annual Precipitation Change $\mathrm{mm}$ per year, 1962-2012

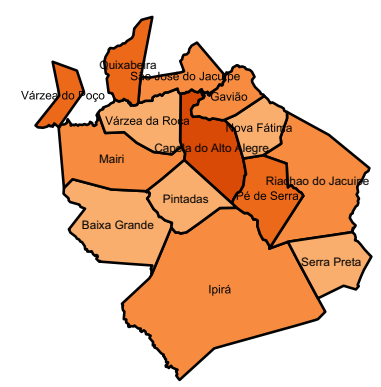

Fig. 2 Climate Trends in the Bacia do Jacuípe a 50-year average trends in temperature and precipitation in the Bacia do Jacuípe (BDJ), aggregated from interpolated INMET climate data. b Change in distribution of precipitation between 1962 and 2012. The number of wet days ( $>1 \mathrm{~mm}$ precipitation) has decreased, while the number of damp days (0-1 mm precipitation) has increased. This lack of nourishing rainfall translates into lower water availability on the ground. c 50-year temperature trends in BDJ, by municipality, ${ }^{\circ} \mathrm{C} / \mathrm{year}$ fitted trend. d 50year precipitation trends in BDJ, by municipality, $\mathrm{mm} / \mathrm{year}$. The entire BDJ region has experienced a strong and significant warming and drying trend over the past half-century. Data from INMET

increases returns to land, as revenues from small dairy operations tend to exceed small-scale staple crop production (most farmers (57 \%) have fewer than 10 ha of agricultural land). Trends for milk production and cattle productivity are shown in the top panels of Fig. 3 for Bahía as a whole and BDJ. Across Bahía, milk production has increased dramatically, with roughly $60 \%$ of the increase in productivity due to increasing number of cattle and $40 \%$ attributable to increased productivity (milk yield per cow). The trends for BDJ contrast starkly. The number of cattle being raised on BDJ farms has risen in a similar fashion (130\% increase), but productivity has actually declined over time.

As shown in Fig. 3, such small-scale dairy farms can be very vulnerable to extreme climate events: in the severe drought of 1993, for example, all of Bahía suffered, with cattle dying and milk production dropping. Recovery took a number of years across the state. In BDJ, however, milk production was decimated: half of the cattle died, and milk production overall dropped by 

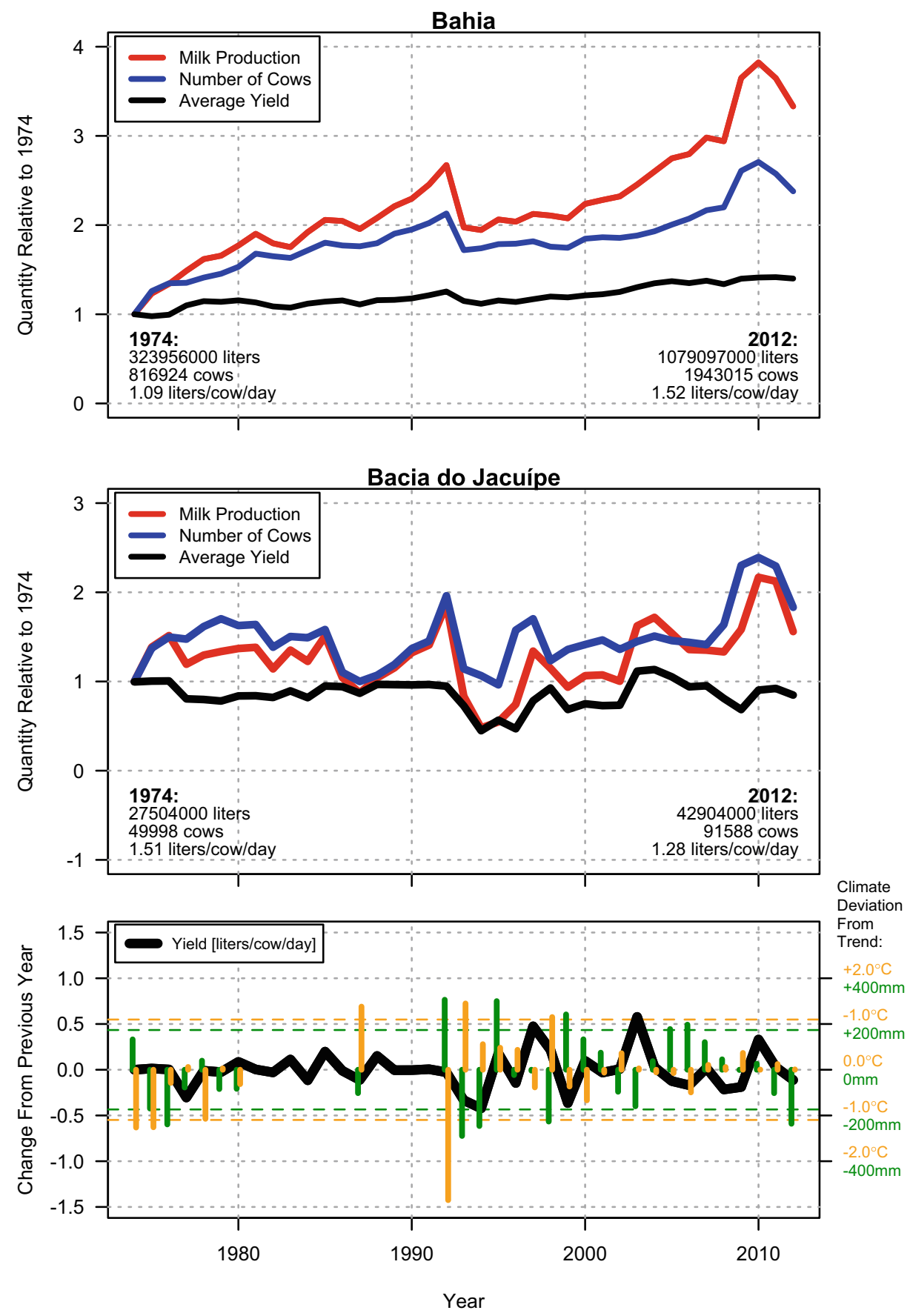
Fig. 3 Diagnosing climate vulnerability. Milk production and productivity in (top) Bahía and (middle) the Bacia do Jacuípe (BDJ) region over the past 4 decades. In 1974, Milk productivity (yield) in BDJ was higher than for Bahia as a whole. Over time, yield has fallen in BDJ but risen steadily in Bahia. In BDJ, production fails to recover after a large climate shock (1993). Milk production in Bahía as a whole suffers after that same climate shock, but more quickly recovers. (bottom) Year-to-year yield changes in BDJ are plotted with annual temperature and precipitation deviations from trend (e.g., Fig. 2a). The dashed lines indicate $+/-1$ standard deviation for precipitation $(174 \mathrm{~mm})$ and temperature $\left(1.1^{\circ} \mathrm{C}\right)$. Regression results showing the relationship between climate and milk productivity are presented in Table S1. Data from IBGE and INMET

$75 \%$. Both the lack of productivity growth over time, and the disproportionate impact of the drought on BDJ indicate a lack of climate resiliency in BDJ vis-a-vis the rest of the state. Indeed, temperature and precipitation are statistically significant predictors of variations in overall yields and in year-to-year changes in yield (productivity per cow) between the municipalities of BDJ, but not for Bahia, over this time period (Fig. 3, bottom, and SI Table 1).

This climate vulnerability has its roots in the dietary requirements of dairy cattle. Milk production depends on three variables in the cattle feed: overall volume (roughage), energetic (caloric) content, and protein content. Attempting to meet these constraints (particularly the volume requirement) on a small land footprint means that farmers are dependent on rainfall to promote forage growth, and reduced rainfall can easily lead to overgrazing and subsequent land compactification and degradation. Although Brazil legally requires all farmers to maintain $20 \%$ of native habitat on their land undisturbed, enforcement is weak or nonexistent (Sparovek et al. 2010). And although agroforestry techniques that preserve trees and native habitat may lead to more productive grazing land in the long run, the incentive to overgraze exists in the short run, particularly in a bad (drought) year. In extreme years, farmers face a terrible choice between letting their cattle eat whatever they can and letting them die.

An examination of agricultural data (IGBE) over the past several decades in BDJ reveals several noteworthy trends. Area planted to corn and cassava (the main food and forage crops) has declined significantly in BDJ since 1990 (Figure S1). Although productivity (yield) has increased slightly over that time (overall production has remained essentially constant), these trends diverge from Bahía as a whole. Across the state, cassava area has remained fairly constant, with productivity rising slightly (similar to BDJ), but corn productivity in the state has increased dramatically (Figure S1b). (Unfortunately, comprehensive crop production at the municipality level data do not exist prior to 1990.)

These two trends - extensification of dairy production (increase in the number of cattle) without milk productivity growth, and decline in forage crop production per cow-have led to large-scale changes in land cover in BDJ. Data from a recent study by Meiyappan and Jain (2012) shows clearly that from 1962 to 2005 , there has been a conversion from native Caatinga shrubland to pastureland in the region as well as in most of the Sertão (Fig. 4). A more detailed spatial analysis study has shown that only $14 \%$ of the caatinga remains in BDJ due to rapid conversion to pasture (Cunha 2012). Perhaps most perversely, this land cover change and degradation - driven in part by rainfall constraints on forage crops - further aggravates the localized effects of global climate change through negative impacts on the water cycle. First, deforestation reduces the recharge of subterranean water systems because vegetation and its root systems, when present, help with the retention and infiltration of the water into the soil, diminishing runoff. Second, increased runoff means increased soil erosion, diminishing soil fertility. Lastly, the reduction of local vegetation reduces the only significant source of local humidity in the region, diminishing the rate of precipitation. Pastoralists are thus locked at present in a vicious cycle of environmental degradation, with desperate need for sustainable adaptation strategies. 

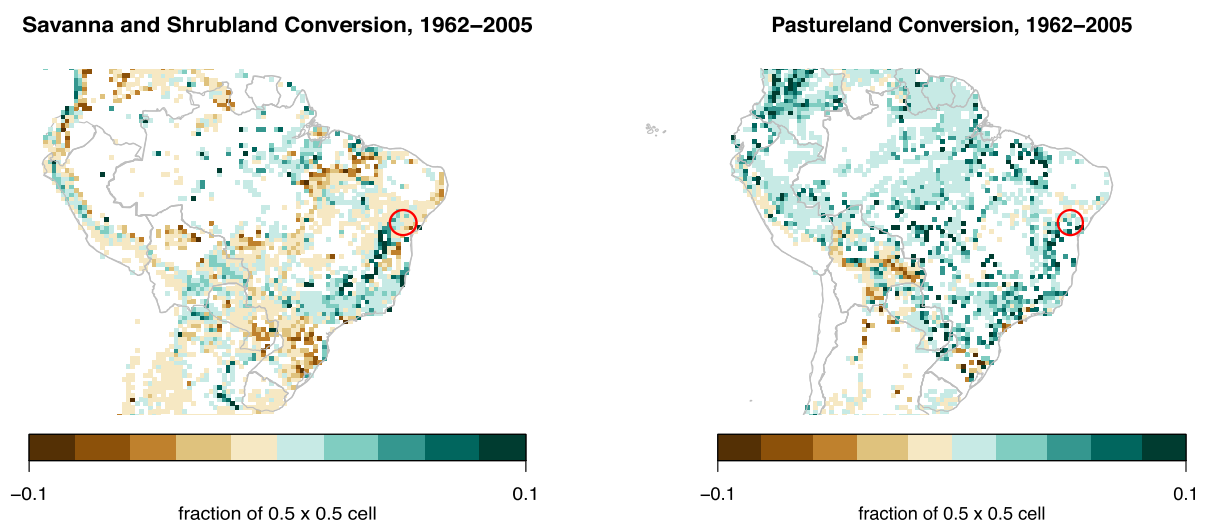

Fig. 4 Land use and vulnerability. Land-use change in Brazil and BDJ. In the Sertão, much native Caatinga landscape has been converted to pastureland, driven by increased reliance on milk production for livelihoods. This deforestation exacerbates regional climate and low productivity problems. Data from Meiyappan and Jain (2012)

It is difficult to pinpoint the exact cause of the wedge between productivity levels in Bahia as a whole (both crop and animal) and productivity levels in BDJ. However, we assume (in line with much of the literature on this type of divergence) that a relative lack of access (both in terms of physical proximity and economic means) to extension services, technical education, and productivity-enhancing technologies plays a leading role.

\section{Testing technologies for climate adaptation in the Sertão}

Results from the irrigation pilot experiment, as well as the improved animal feed experiments for milk and meat production, are presented in Tables S2, S3, and S4, respectively. (It should be noted that all tables contain monetary values in Brazilian Real (R\$), with 1USD 2R \$ at present.)

\subsection{Smallholder irrigation}

Adapta Sertão's irrigation pilot study financed small irrigation systems for 8 farmers and followed their progress for several years, from 2007 into the drought of 2010-2013. These are some of the longest detailed economic studies of irrigation systems with smallholder farmers available. Furthermore, farmers financed purchase of these systems through Adapta Sertão and were making loan repayments during the period of study. This differs dramatically from many existing studies that have examined impacts of efficient irrigation in the context of development projects where the equipment has been given to beneficiaries (e.g., Moyo et al. 2006, Burney and Naylor 2012).

Table S2 presents the results of harmonized investment analysis on these systems. Physical details about the individual irrigation systems are given at the top of the table, followed by fixed and operating costs. Revenues include both the sale of products from the irrigated gardens and the value of produce consumed by the household. Profit is calculated in several ways: (1) total revenue minus total costs since installation; (2) average monthly profit, where the total profit is divided across the entire time period since installation; and (3) average monthly profit across operational months, where the total profit is divided only among months where the system was being used. Net Present Value (NPV) and Internal Rate of Return (IRR) 
are calculated over a 5 year time period. Finally, we include labor analysis where we document the total labor, and the portion of that labor by the system owner. We then calculate the returns to that labor $(\mathrm{R} \$ / \mathrm{h})$.

As shown in Table S2, the systems studied varied in size and technology, although all were 1 ha or smaller. Size and system geometry were determined in consultation with each farmer, taking into account land layout, water source, and desired crops. In this study, the farmers produced a variety of vegetables and other crops using these systems, and chose when and how to operate them. Data for investment analysis were gathered during technician visits to the farms. Most of the systems were profitable, and significantly so, even when not including the value of work for the farmer. The median internal rate of return was $53 \%$. During the period farmers were using the systems, their income was comparable with the average local salary in the region outside farming (i.e. school teacher, social servant, etc.), when including the opportunity cost of mechanical water pumping.

Farmers with irrigation were able to produce, consume, and sell much more food than the period without irrigation (see revenues in Table S1). It is worth noting that farmers were selling a large percentage of their cultivated products, keeping an average of $16 \%$ (by value) for home consumption. These numbers agree with previous detailed studies of irrigated vegetables production in developing semi-arid communities (e.g., Burney et al. 2010). Farmers also reported substantial livelihood improvement as they ceased to spend up to $4 \mathrm{~h}$ per day in fetching water. The majority of the farmers were engaged in irrigated vegetable production as a part-time activity (behind milk/meat production), but of those who did take on vegetable production as their main activity (farmers 4, 6, 7, and 8), several outperformed the other farmers.

An important caveat to these data is that, on average, the irrigation systems were used for only $58 \%$ of the time they were installed. The remaining $42 \%$ of the time they were idle due to lack of water access. (Correspondingly, profit over operational months is roughly a factor of two higher than profit over all months since installation.) A majority of BDJ farmers use small, earthen dams called açudes for irrigation. For varying amounts of time, these dams run dry during the annual dry season (from September to January). As such, BDJ farmers participating in this experiment could not irrigate year-round and therefore only reached a fraction of their production capacity. More severe droughts further limited productivity. During the heavy drought of 2012, none of the farmers were able to irrigate because all water sources dried out; farmers could not produce enough revenue from their systems to make loan repayments. These data suggest that irrigation is fundamentally limited as an adaptation strategy by overall water access. This is discussed in greater detail below, and in the SI.

\subsection{Balanced animal feed}

Prior to the interventions, none of the dairy or goat farmers had received training on feed calculations for their livestock; consequently, none were feeding their animals an appropriate balance of roughage, carbohydrates (energy), and protein. With consultation for the particular breed of animal, feeding plans were devised. Animal milk production and weight gain were monitored before and after introduction of balanced feed; results are presented in Tables S3 and S4 for milk and meat, respectively.

Table S3 presents the results for the dairy cow experiment. Baseline values of productivity and feed costs (the non-optimized baseline feeding practices) are presented, as well as values at the end of the pilot period. At the end of 1 month, milk productivity increased, on average, by $52 \%$ (Table S3). Net income from milk production also rose dramatically (49\% average). Although productivity rose for all cows, one cow saw net income decrease; it was later determined that this cow was nearing the end of her lactation period when the experiment 
began. (Excluding this cow from the analysis results in an average productivity increase of $57 \%$ and a profit increase of $65 \%$ ).

The data for the meat experiment (Table S4) are similarly impressive. For reference, pastured goats typically gain $1 \mathrm{~kg} /$ month, so the 30 - and 45 - day weight gains represent changes 4 or 5 times the baseline expectation. At the end of 45 days, one farmer's goats had gained an average of $2.8 \mathrm{~kg}$ of muscle mass (meat), or an increase of $19.5 \%$; the other farmer's goats had gained $4.3 \mathrm{~kg}(26 \%)$ more meat after 30 days. The two farmers earned a net profit per animal of $\$ 129$ and $\$ 148$, respectively. These profits are directly proportional to the additional muscle mass gained by the animals (as payment is based on weight of meat when butchered).

These data for the returns to a fairly straightforward diet optimization are encouraging; limitations to this study and policy implications are discussed in detail below.

\section{Discussion}

This study aims (i) to outline the impact of climate change on key local food chains of the Bacia do Jacuipe county, Bahia; and (ii) test and evaluate the contribution that efficient irrigation and a balanced animal feed could have in increasing farmers' resilience in the study area. This is necessary step to start building a database of strategies and technologies shown to work locally and that could incorporated, in a bottom-up fashion, into specific development and climate change adaptation programs.

The drip irrigation study here represents some of the longest data on the use of irrigation in developing communities and is thus immensely valuable. These data suggest that irrigation is only a moderately effective adaptation strategy, since in the worst years, lack of reliable water access precluded use. This study has further underscored that irrigation with ephemeral water sources is inherently risky and may not be economically viable during drier periods. (This corroborates earlier work, e.g. Burney and Naylor 2012.) To be a successful adaptation strategy, irrigation thus requires additional work to secure water access year-round, through storage, access to groundwater, or construction of larger catchments. The Brazilian government has undertaken several projects to construct water cisterns for smallholders in the Sertão and elsewhere; an obvious departure point for future research would be to test the effectiveness of irrigation in conjunction with cisterns. It would be important to understand whether such cisterns outperform the acudes.

However, if access to a stable water supply is secured such that farmers are able to use systems year-round, the data from this pilot project are very promising. Including the value of garden products consumed at home (as an offset cost), the median net profit to date for all eight farmers is $\mathrm{R} \$ 1,361$. Assuming variable costs remain similar, after payback of the initial capital investment median annual profit is over $\$ 3,300$. The Net Present Value (NPV) of all of the systems $(10 \%, 5$ years) is positive (median $=\$ 8,403)$, and all systems have an Internal Rate of Return (IRR) over $10 \%$, a common metric for development projects reflecting the likely cost of capital through private channels. If used year-round, payback time for the systems ranges from just under 1 year to just over 3 years (for the PV system).

The milk and meat trials were very successful. Overall, these results heavily support extension and education on balanced feeding practices, since this simple education pilot to help farmers optimize their cattle feed had profound impacts on productivity and profit. The milk trial was too short and small to include any impacts on landcover, but these data suggest that dairy farmers in the Sertão should be able to intensify production profitably, and at the same time lessen impact on the environment. However, programs built around improved 
feeding practices will have to come with an understanding to the limits farmers' land impose on voluminous roughage. That is, technical advisers to dairy farmers should help farmers maximize their own forage production and then size their herd accordingly. Many pastoralists in the area have started producing new forage crops, like palma forageira (prickly pear cactus), which improves the volume of roughage available without contributing to the rampant problem of overgrazing and subsequent habitat loss, deforestation, drying, and soil compactification. Future research should study, in a controlled manner, the impact use of palma has on productivity and landcover. This would be an important contribution to the literature exploring the possibilities of simultaneous economic and environmental sustainability in smallholder production systems.

\section{Policy relevance and conclusions}

Northeastern Brazil has long featured a top-down policy-led approach, where the Federal and State governments collaborate to address specific needs. Gutiérrez et al. (2014) made one of the most detailed and comprehensive description of policies and programs that are currently used to alleviate droughts impacts in semi-arid Brazil. These range from water truck programs to insurance, well drilling, cash transfer ("Bolsa estiagem") and credit, among others. Although all of these programs have been justified as emergency measures, these actions come without clear discussion about what kinds of technologies should be bought with government funds to decrease the impact of drought. Moreover, the categorization of these interventions as "emergency" actions means they are put in place when conditions are already straining smallholders, and none of these policies are put into a longer climate change perspective. Resilience is not about response to any one particular climate event, but is instead built through timeespecially during good rainy years, when the farmer has time and resources to organize his/ her farm to face longer droughts.

Climate records show that over the last 50 years, average annual precipitation in BDJ has decreased by more than $300 \mathrm{~mm}(-30 \%)$ and average daily temperature has increased by approximately $2{ }^{\circ} \mathrm{C}$ (twice the global average for the latter). These changes have altered smallholder life, pushing farmers into pastoralism as staple crop production has become less and less profitable. Nevertheless, this shift has not protected smallholders from climate vulnerability. Recent records show extreme sensitivity of livestock to climate in BDJ: rising temperatures, decreasing rainfall and increasing deforestation rates expose livestock to everincreasing environmental stress, thereby reducing their productivity. Milk production has already decreased significantly in BDJ. Such conditions make it difficult for farmers to grow their own feedstock. Worst of all, forecast climate trends threaten to further undermine the region's agriculture and livestock industry - the primary source of economic productivity. The severe drought of 2010-2012 highlights the socio-economic vulnerability of the region.

The Adapta Sertão coalition has tried to understand, through applied research at a farm level, how balanced animal feeding practices and the use of water-efficient irrigation systems can break this vicious cycle of low agricultural productivity and environmental degradation. Our pilot results on efficient irrigation and improved animal feeding practices show tremendous promise, and highlight important considerations for policymakers. First, irrigation and feeding practices are both profitable, but fundamentally limited by water availability (total stored capacity for irrigation, and production of forage for livestock). Programs to augment smallholder water access, through catchments or groundwater access, are therefore key for maximizing returns to irrigation investments. It is important that where such programs are introduced, groundwater extraction be regulated based on the recharge rate of the aquifer so as 
not to deplete groundwater resources, as has happened elsewhere in Bahia. Likewise, extension programs to promote balanced feeding practices must be accompanied by programs that help smallholders grow more forage on less water and a smaller land footprint, and help them rehabilitate degraded lands for better forage productivity. Such programs must be accompanied by institutions and policies that will enable farmers to more easily access supplemental protein and calorie feeds. (For example, farmers in BDJ were able to access these feeds through farmer cooperatives, which may need to be strengthened in other regions.) Both irrigation and balanced feed initiatives could be integrated with comprehensive soil management programs.

The magnitude (and strong statistical significance) of climate trends in BDJ in recent decades underscores the need for policy support in mainstreaming specific strategies and technologies (like the ones outlined in this study). The process outlined here-understanding localized climate impacts and the region-specific dynamics of smallholder vulnerabilityshould be undertaken across the Sertão, where climate trends and conditions may differ. Policies and programs rooted in these findings can then help simultaneously make farmers more resilient to climate change impacts and sustain the local bioma - the caatinga - at the basis of regional agricultural production

Acknowledgments This project was supported by the Climate Development and Knowledge Network $(\mathrm{CDKN})$.

Open Access This article is distributed under the terms of the Creative Commons Attribution License which permits any use, distribution, and reproduction in any medium, provided the original author(s) and the source are credited.

\section{References}

Antonino ACD, Hammecker C, Montenegro S et al (2005) Subirrigation of land bordering small reservoirs in the semi-arid region in the Northeast of Brazil: monitoring and water balance. Agric Water Manag 73:2

Archer ERM (2004) Beyond the 'climate versus grazing' impasse: using remote sensing to investigate the effects of grazing system choice on vegetation cover in the eastern Karoo. J Arid Environ 57:3

Assad ED, Buainain AM, Pinto H et al (2013) Climate change - challenges for Brazil. In: Vajpeyi DK (ed) Climate change, sustainable development, and human security: a comparative analysis. Lexington Books, Plymouth, UK

Berman R, Quinn C, Paavola J (2012) The role of institutions in the transformation of coping capacity to sustainable adaptive capacity. Environ Dev 2:86-100

Burney J, Naylor R (2012) Smallholder irrigation as a poverty alleviation tool in Sub-Saharan Africa. World Dev 40:1

Burney J, Woltering L, Burke M et al (2010) Solar-powered drip irrigation enhances food security in the SudanoSahel. PNAS 107:5

Cunha JU (2012) Conservação da Biodiversidade no Território da Bacia do Jacuípe. (Biodiversity conservation on the Bacia do Jacuípe County). Master Thesis. IPE/Escola Superior de Conservação Ambiental e Sustentabilidade

D’Andrade W (2012) Nordeste recebe metade dos benefícios do Bolsa Família em dezembro. Econ Negocios

Dubeux JCB et al (2006) Productivity of Opuntia ficus-indica (L.) Miller under different N and P fertilization and plant population in north-east Brazil. J Arid Environ 67:3

Gutiérrez APA, Engle N, De Nys E et al (2014) Drought preparedness in Brazil weather and climate extremes, available online before print

Holling CS (1973) Resilience and stability of ecological systems. Annu Rev Ecol Syst 4:1-23

IBGE (Brazilian Institute of Geography and Statistics), crop database: Available at: http://www.ibge.gov.br/

IBGE (Brazilian Institute of Geography and Statistics) (2006) Available at: http://www.ibge.gov.br/home/ estatistica/economia/pibmunicipios/2006/tab01.pdf 
INMET (Instituto Nacional de Meteorologia) database: http://www.inmet.gov.br/portal/index.php?r=estacoes/ mapaEstacoes

Jat RA, et al (2012) Conservation agriculture in the semi-arid tropics: prospects and problems. In: Sparks DL (ed) Advances in agronomy. Academic Press, San Diego, CA

Krol MS, Bronstert A (2007) Regional integrated modelling of climate change impacts on natural resources and resource usage in semi-arid Northeast Brazil. Environ Model Softw 22(2):256-268

Krol MS, Jaeger A, Bronstert A et al (2006) Integrated modelling of climate, water, soil, agricultural and socioeconomic processes: a general introduction of the methodology and some exemplary results from the semi-arid north-east of Brazil. J Hydrol 328:3-4

Lima PCF (1986) Tree productivity in the semiarid zone of Brazil. For Ecol Manag 16:1-4

Lobell DB, Burke MB, Tebaldi C et al (2008) Prioritizing climate change adaptation needs for food security in 2030. Science 319:5863

Lobell DB, Schlenker W, Costa-Roberts J (2011) Climate change and global crop production since 1980. Science 333:6042

MDA/Ministry of Agricultural Development (2012) "Plano Safra da agricultura familiar 2012/2013" available at: http://portal.mda.gov.br/plano-safra/arquivos/view/Cartilha_Plano_Safra.pdf

Meiyappan P, Jain A (2012) Three distinct global estimates of historical land-cover change and land-use conversions for over 200 years. Front Earth Sci 6:2

Mogotsi K, Nyangito MM, Nyariki DM (2013) The role of drought among agro-pastoral communities in a semiarid environment: the case of Botswana. J Arid Environ 91:38-44

Montenegro S, Ragab R (2012) Impact of possible climate and land use changes in the semi arid regions: a case study from North Eastern Brazil. J Hydrol 434-435:55-68

Moyo R, Love D, Mul M et al (2006) Impact and sustainability of low-head drip irrigation kits, in the semiarid Gwanda and Beitbridge Districts, Mzingwane Catchment, Limpopo Basin, Zimbabwe. Phys Chem Earth Parts $\mathrm{A} / \mathrm{B} / \mathrm{C} 31: 15-16$

Obermaier M, Maroun MR, Kligerman DC et al (2009) Adaptation to climate change in Brazil: the Pintadas pilot project and multiplication of best practice examples through dissemination and communication networks. In: Rio 9 world climate \& energy event, Anais. Rio de Janeiro. Proceedings. GTZ, Rio de Janeiro, pp 185-190

Rockström J (2003) Resilience building and water demand management for drought mitigation. Phys Chem Earth Parts A/B/C 28:20-27

Rodrigues da Silva VP (2004) On climate variability in Northeast of Brazil. J Arid Environ 58:4

Silva VPR, Campos JHBC, Silva MT et al (2010) Impact of global warming on cowpea bean cultivation in northeastern Brazil. Agric Water Manag 97:11

Simões AF, Kligerman DC, La Rovere EL et al (2010) Enhancing adaptive capacity to climate change: the case of smallholder farmers in the Brazilian semi-arid region. Environ Sci Pol 13:8

Sparovek G, Berndes G, Klug ILF, Barretto AGOP (2010) Brazilian agriculture and environmental legislation: status and future challenges. Environ Sci Technol 44:16 